\title{
Shewanella waksmanii sp. nov., isolated from a sipuncula (Phascolosoma japonicum)
}

\author{
Elena P. Ivanova, ${ }^{1,2}$ Olga I. Nedashkovskaya, ${ }^{1}$ Natalia V. Zhukova, ${ }^{3}$ \\ Dan V. Nicolau, ${ }^{2}$ Richard Christen ${ }^{4}$ and Valery V. Mikhailov ${ }^{1}$
}

Correspondence

Elena P. Ivanova

eivanova@swin.edu.au

\author{
${ }^{1}$ Pacific Institute of Bioorganic Chemistry of the Far-Eastern Branch of the Russian Academy \\ of Sciences, 690022 Vladivostok, Pr. 100 Let Vladivostoku 159, Russia \\ ${ }^{2}$ Industrial Research Institute, Swinburne University of Technology, PO Box 218, Hawthorn, \\ Victoria 3122, Australia \\ ${ }^{3}$ Institute of Marine Biology of the Far-Eastern Branch of the Russian Academy of Sciences, \\ 690038, Palchevskogo Str. 17, Vladivostok, Russia
${ }^{4}$ UMR 6078 CNRS and Université Nice Sophia-Antipolis, Bat. J. Maetz, F06238 Villefranche sur mer cedex, France

Two marine bacterial strains, $\mathrm{KMM} 3823^{\top}$ and $\mathrm{KMM} 3836$, isolated from a sipuncula (Phascolosoma japonicum), a common inhabitant of Troitsa Bay in the Gulf of Peter the Great (Sea of Japan), were studied. Comparative 16S rRNA gene sequence-based phylogenetic analysis placed these bacteria into a separate branch of the 'Gammaproteobacteria' within members of the genus Shewanella. KMM $3823^{\top}$ showed the highest similarity (96.6\%) with Shewanella fidelis. The DNA G $+\mathrm{C}$ contents of the two strains studied were $43.0 \mathrm{~mol} \%$. The level of DNA homology between these two strains was conspecific (93\%), indicating that they represent a single genospecies. These organisms were greenish-brown, Gram-negative, polarly flagellated, facultatively anaerobic, mesophilic (temperature range $4-30^{\circ} \mathrm{C}$ ), neutrophilic, haemolytic and were able to degrade elastin, gelatin and DNA. They were susceptible to ampicillin, carbenicillin, gentamicin and kanamycin. The predominant fatty acids were characteristic for shewanellas: $13: 0-i, 15: 0-i$ and $16: 1(n-7)$; up to $6 \cdot 7 \%$ of eicosapentaenoic fatty acid, $20: 5(n-3)$, was produced during growth at $28^{\circ} \mathrm{C}$. Phylogenetic evidence, confirmed by DNA hybridization and phenotypic characteristics revealed that the two bacteria studied constitute a new species,

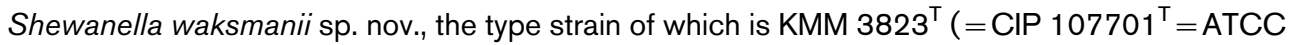
BAA $-643^{\top}$ ).
The genus Shewanella MacDonell and Colwell 1985 comprises a group of Gram-negative, aerobic and facultatively anaerobic 'Gammaproteobacteria' frequently isolated from aquatic habitats and also from clinical sources (MacDonell \& Colwell, 1985; Gauthier et al., 1995; Venkateswaran et al., 1999). Shewanella species represent one of the most numerically abundant micro-organisms among readily cultivated marine proteobacteria and currently comprise about 20 species whose names have been validly published. During the last decade, members of this genus have been studied extensively due to their important role in co-metabolic bioremediation of halogenated organic pollutants (Petrovskis et al., 1994), destructive

The GenBank/EMBL/DDBJ accession number for the 16S rDNA sequence of Shewanella waksmanii $\mathrm{KMM} 3823^{\top}$ is $\mathrm{AY} 170366$.

A full phylogenetic tree and a table showing the complete cellular fatty acid composition of Shewanella waksmanii is available as supplementary data in IJSEM Online. souring of crude petroleum (Semple \& Westlake, 1987), the dissimilatory reduction of manganese and iron oxides (Myers \& Nealson, 1988), and their ability to produce high proportions of polyunsaturated fatty acids (Russel \& Nichols, 1999).

In this study we report on the characterization of new bacteria of the genus Shewanella isolated from the sipuncula (peanut worm) Phascolosoma japonicum collected in Troitsa Bay in the Gulf of Peter the Great (Sea of Japan). This work was part of a taxonomic investigation of free living and symbiotrophic marine bacteria from the northwestern Pacific Ocean. During the course of this work 70 presumptive Shewanella species of three phenotypes were isolated. The majority of the strains had Shewanella japonica-like phenotype, several had Shewanella colwellianalike phenotype (E. P. Ivanova et al., unpublished). Only two isolates described here had a number of particular phenotypic properties and formed a separate phylogenetic 
clade amongst other previously described Shewanella species. Analysis of the results obtained has led us propose the name Shewanella waksmanii sp. nov. for the new strains.

Benthic marine worms (three examples) of the phylum Sipuncula, Phascolosoma japonicum, were collected in 1997 from a depth of $3-5 \mathrm{~m}$ (salinity, $32 \%$, temperature, $18{ }^{\circ} \mathrm{C}$ ) at the Pacific Institute of Bio-organic Chemistry Marine Experimental Station, in Troitsa Bay, the Gulf of Peter the Great (Sea of Japan). The invertebrates were dissected under aseptic conditions. A tissue homogenate $(0 \cdot 1 \mathrm{ml})$ was plated onto Marine 2216 agar (Difco) or medium B which contained $0 \cdot 2 \%(\mathrm{w} / \mathrm{v})$ Bacto Peptone (Difco), $0 \cdot 2 \%$ $(\mathrm{w} / \mathrm{v})$ casein hydrolysate (Merck), $0 \cdot 2 \%(\mathrm{w} / \mathrm{v})$ Bacto Yeast Extract (Difco), $0 \cdot 1 \%(\mathrm{w} / \mathrm{v})$ glucose, $0 \cdot 02 \%(\mathrm{w} / \mathrm{v}) \mathrm{KH}_{2} \mathrm{PO}_{4}$, $0.005 \%(\mathrm{w} / \mathrm{v}) \quad \mathrm{MgSO}_{4} .7 \mathrm{H}_{2} \mathrm{O}, 1.5 \%(\mathrm{w} / \mathrm{v})$ Bacto agar (Difco), $50 \%(\mathrm{v} / \mathrm{v})$ of natural sea water, and $50 \%(\mathrm{v} / \mathrm{v})$ distilled water at $\mathrm{pH} 7 \cdot 8$. Plates were incubated aerobically at room temperature (approx. $22-25^{\circ} \mathrm{C}$ ) for 5,7 or 10 days. The isolation and purification of the bacterial strains was as described previously (Ivanova et al., 1996). Strains were stored at $-80^{\circ} \mathrm{C}$ in Marine 2216 broth (Difco) supplemented with $20 \%(\mathrm{v} / \mathrm{v})$ of glycerol. In total seven presumptive Shewanella strains out of 45 strains of viable bacteria have been recovered from sipunculas tissue homogenates. Five strains had Shewanella colwelliana-like phenotypes and two strains had distinct phenotypic traits and were studied further in detail.

Unless otherwise indicated, the phenotypic characteristics were studied using standard procedures (Baumann et al., 1972; Smibert \& Krieg, 1994) as described elsewhere (Ivanova et al., 1996). The tests for utilization of various organic substrates as sole carbon sources at a concentration of $0 \cdot 1 \%(\mathrm{w} / \mathrm{v})$ were performed in $10 \mathrm{ml}$ tubes of liquid BM medium (Baumann et al., 1972). The bacteria were grown with shaking on a rotary shaker at 160 r.p.m. for $72 \mathrm{~h}$ at $25^{\circ} \mathrm{C}$. The ability to oxidize organic substrates was investigated using Biolog-GN plates as described previously (Ivanova et al., 1998). The following physiological and biochemical properties were examined: oxidation/ fermentation of glucose, denitrification, catalase and oxidase activities, gelatin liquefaction, arginine dihydrolase, lysine decarboxylase, ornithine decarboxylase, indole and $\mathrm{H}_{2} \mathrm{~S}$ production, the ability to hydrolyse starch, alginate, chitin, elastin, Tween 80 and casein, and the ability to produce lecithinase. The requirement for $\mathrm{Na}^{+}$ions was studied on medium that contained (w/v) $0.25 \%$ yeast extract, $0 \cdot 1 \%$ glucose, $0 \cdot 02 \% \mathrm{KH}_{2} \mathrm{PO}_{4}, 0 \cdot 005 \%$ $\mathrm{MgSO}_{4} .7 \mathrm{H}_{2} \mathrm{O}(\mathrm{pH} 7 \cdot 8)$. Salt tolerance tests were performed on trypticase soy agar (TSA; Difco) with $\mathrm{NaCl}$ concentrations of $0 \cdot 6-20 \cdot 0 \%(\mathrm{w} / \mathrm{v})$. Dissimilatory iron reduction was tested on LM medium $[0.02 \%(\mathrm{w} / \mathrm{v})$ yeast extract, $0.01 \%(\mathrm{w} / \mathrm{v})$ peptone, $0.6 \%(\mathrm{w} / \mathrm{v}) \mathrm{NaCl}, 10 \mathrm{mM}$ sodium bicarbonate, $10 \mathrm{mM}$ HEPES] supplemented with carbon substrates as appropriate $(5 \mathrm{mM}$ lactate, $5 \mathrm{mM}$ succinate, $5 \mathrm{mM}$ glycerol, $1 \mathrm{mM}$ acetate), $50 \mathrm{mM}$ ferric citrate, $5 \mathrm{mM}$ sodium molybdate and the colour reagent ferrozine [3-(2-pyridyl)-5,6-bis(4-phenylsulfonic acid)$1,2,4$ triazine, $\mathrm{pH} 7 \cdot 2$ ] in distilled water. Plates were inoculated and incubated anaerobically at room temperature (approx. $7 \mathrm{~d}$ ) (with positive and negative controls). Colonies displaying cleared zones were scored as positive for iron reduction.

Haemolytic activity of the strains studied was detected on blood agar (TSA, $40 \mathrm{~g} \mathrm{l}^{-1}$; sheep blood, $50 \mathrm{ml}$; water, $950 \mathrm{ml}$ ). Haemolytic activity on mouse erythrocytes and cytotoxicity on Ehrlich cells were tested on butanol extracts of the strains as described earlier (Ivanova et al., 2001). Antibacterial activity was performed by the agar diffusion assay, based on the method described by Barry (1980). Cultures $(0 \cdot 1 \mathrm{ml})$ of indicator test strains were spread on TSA plates in which circular wells (diameter, $10 \mathrm{~mm}$ ) had been cut. Samples $(0.1 \mathrm{ml})$ of butanol extracts of the isolates were added to the wells and areas of inhibited bacterial growth were measured after incubation for $48 \mathrm{~h}$ at $28{ }^{\circ} \mathrm{C}$. Zones of inhibited growth of the indicator strains surrounding the wells were observed. Mean diameters were measured, and $10 \mathrm{~mm}$ subtracted (representing the diameter of the well). Antibacterial activities were tested against Staphylococcus aureus CIP $103594^{\mathrm{T}}$, Escherichia coli ATCC 15034, Proteus vulgaris NBRC (formerly IFO) $3851^{\mathrm{T}}$, Enterococcus faecium CIP 104105, Bacillus subtilis ATCC $6051^{\mathrm{T}}$ and the yeast Candida albicans KMM 455. Analysis of fatty acid methyl ethers was performed by GLC as described by Svetashev et al. (1995).

The DNA was extracted from cells grown overnight on B medium following the method of Marmur (1961). The mol\% G $+\mathrm{C}$ content of the DNA was determined by HPLC (Tamaoka, Komagata, 1984). Levels of genetic relatedness were determined by the fluorometric microdilution plate method (Ezaki et al., 1988; Sawabe et al., 1998). The 16S rRNA gene was amplified and sequenced by MIDI Labs (Newark, USA). Briefly, primers used for the amplification corresponded to Escherichia coli positions 5 and 1540. Amplification products were purified using Microcon 100 (Millipore) molecular mass cut-off membranes and checked for quality and quantity on an agarose gel. Cycle sequencing of the 16S rRNA gene amplification products was carried out using AmpliTaq ES DNA polymerase and Rhodamine dye terminators. The samples were electrophoresed on an ABI Prism 377 DNA Sequencer.

The new $16 \mathrm{~S}$ rDNA sequence was automatically and then manually aligned by reference to a database of 35000 already aligned bacterial 16S rRNA gene sequences. Phylogenetic trees were constructed according to three different methods (BioNJ, maximum-likelihood and maximumparsimony). The BioNJ program from Gascuel (1997), maximum-likelihood and maximum-parsimony programs were from PHYLIP (Phylogeny Inference Package, version $3.573 \mathrm{c}$, distributed by J. Felsenstein, Department of Genetics, UW, Seattle, WA, USA). For the NJ analysis, a matrix distance was calculated according to the Kimura two-parameter correction. Bootstraps were done using 500 
replications, BioNJ and Kimura two-parameter corrections. The phylogenetic trees were drawn using NJPLOT (Perrière \& Gouy, 1996) and ClarisDraw software for Apple Macintosh. Domains used to construct phylogenetic trees were regions of the small-subunit rDNA sequences available for all sequences and excluding positions likely to show homoplasy.

Strains KMM $3823^{\mathrm{T}}$ and 3836 formed circular, smooth and convex colonies with an entire edge, slightly brown to greenish, 3-5 $\mathrm{mm}$ in diameter after 2 days incubation at room temperature (approx. $22-24^{\circ} \mathrm{C}$ ). Cells of both strains were rod-shaped, $1-2 \mu \mathrm{m}$ in length and $0 \cdot 6-0.8 \mu \mathrm{m}$ in diameter, polarly flagellated and Gram-negative. They did not form endospores. They were phenotypically similar to Shewanella species. Both strains were able to grow anaerobically by fermentation of glucose, a feature observed in some other species of Shewanella: Shewanella frigidimarina, Shewanella gelidimarina, Shewanella hanedai and
Shewanella benthica, but the new bacteria did not reduce ferric compounds. Strains KMM $3823^{\mathrm{T}}$ and 3836 did not require organic growth factors. They had an absolute requirement in $\mathrm{Na}^{+}$ions and grew well at 1-6\% NaCl; no growth was detected at $8 \% \mathrm{NaCl}$. The temperature range was $4-30{ }^{\circ} \mathrm{C}$ (optimum at $20-25^{\circ} \mathrm{C}$ ); no growth was detected at $35^{\circ} \mathrm{C}$. The $\mathrm{pH}$ values for growth were $6 \cdot 0-10 \cdot 0$ (optimum pH 7.5). Both strains were oxidase-, catalase-, haemolysis-positive, but had no cytotoxic or antibacterial activities. Both strains were susceptible to ampicillin and carbenicillin. Strain KMM 3836 indicated susceptibility to gentamicin and kanamycin as well. The novel Shewanella isolates were positive for elastase, gelatinase and DNAase, but negative for amylase, agarase, alginase, laminaranase, chitinase and were able to utilize a wide range of the following carbohydrates (according to Biolog): $\alpha$-D-glucose, Tween 40, Tween 80, $N$-acetyl-D-glucosamine, adonitol, Darabitol, i-erythritol, D-mannitol, L-rhamnose, D-trehalose,

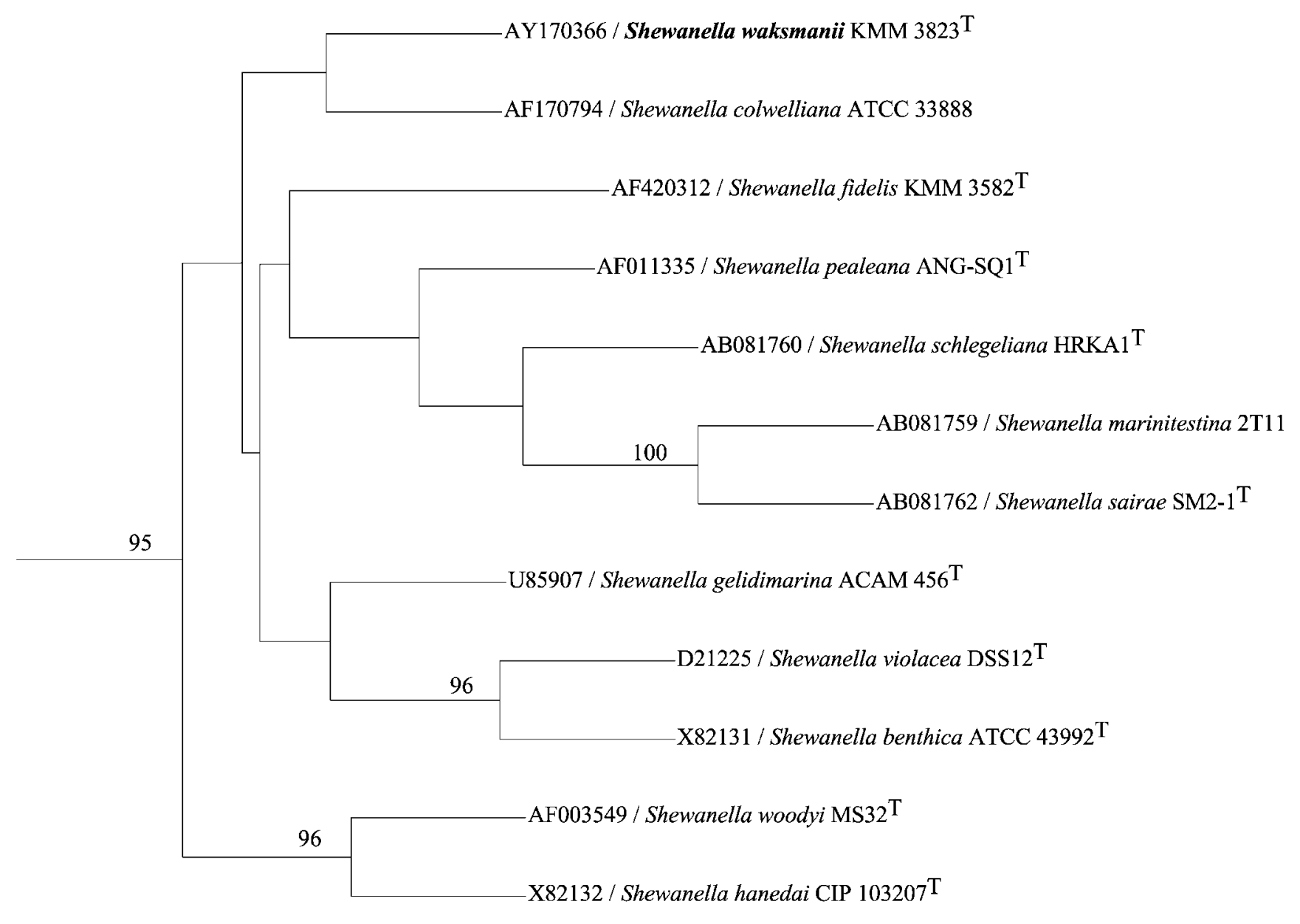

Fig. 1. Phylogenetic position of Shewanella waksmanii according to $16 \mathrm{~S}$ rRNA gene sequence analysis. Rooted tree, subset of topology obtained using the BioNJ algorithm and 1000 bootstrap replications with a Kimura two-parameters correction for the distances. Percentage bootstrap values are indicated only for branches that were also retrieved by maximum-parsimony and maximum-likelihood $(P<0.01)$; these branches should be considered as the only robust clusters identified by this analysis. Shewanella waksmanii does not cluster with any other species of Shewanella, suggesting that it is a new species. A fuller version of this tree is available as supplementary data in IJSEM Online. 
xylitol, methylpyruvate, acetic acid, cis-aconitic acid, citric acid, formic acid, D-gluconic acid, $\beta$-hydroxybutyric acid, $p$-hydroxyphenylacetic acid, $\alpha$-ketoglutaric acid, DL-lactic acid, propionic acid, quinic acid, sebacic acid, D-mannose, succinic acid, glycyl-L-glutamic acid, D-alanine, L-alanine, laninamide, L-alanyl glycine, L-asparagine, L-aspartic acid, L-glutamic acid, L-histidine, hydroxy L-proline, L-ornithine, L-proline, L-serine, L-pyroglutamic acid, DL-carnitine, urocanic acid, inosine, uridine, L-glutamic acid, L-ornithine, glycerol, DL- $\alpha$-glycerol phosphate. Dextrin, m-inositol, L-leucine and uridine were weakly utilized. Phenotypic analysis showed that both isolates were essentially identical to each other and differed only in the susceptibility to gentamicin and kanamycin.

The $\mathrm{G}+\mathrm{C}$ content of the DNA was $43 \cdot 0 \pm 0 \cdot 4 \mathrm{~mol} \%$ for strain $\mathrm{KMM} 3823^{\mathrm{T}}$ and $42 \cdot 9 \pm 0 \cdot 4 \mathrm{~mol} \%$ for strain $\mathrm{KMM}$ 3836. DNA-DNA hybridization data revealed a high level of DNA relatedness between KMM $3823^{\mathrm{T}}$ and KMM 3836 (up to $93 \%$ ). On the other hand DNA from the KMM $3523^{\mathrm{T}}$ showed rather low relatedness (16-9\%) with the DNAs of the two phylogenetically closest strains Shewanella fidelis KMM $3582^{\mathrm{T}}$ and Shewanella colwelliana ATCC $39565^{\mathrm{T}}$. These data clearly indicated that the new strains belong to the same genospecies which constitutes a separate species (Wayne et al., 1987; Stackebrandt \& Goebel, 1994).

The cellular fatty acids ranged from $\mathrm{C} 12$ to $\mathrm{C} 18$ and included saturated, monoenoic monounsaturated, straightchain and iso-branched components (Table 2). In both strains $13: 0-\mathrm{i}, 15: 0-\mathrm{i}, 15: 0,16: 0,16: 1(\mathrm{n}-7), 17: 1(\mathrm{n}-8)$ and $20: 5(n-3)$ were major components. The level of branched fatty acids was up to $50 \%$ of the total fatty acids for KMM $3823^{\mathrm{T}}$. Notably, eicosapentaenoic fatty acid, $20: 5(n-3)$ (up to $6 \cdot 7 \%$ ) and a high proportion of 15:0-i were produced during growth at $28^{\circ} \mathrm{C}$. In their main features, the fatty acid profiles were similar to those reported for Shewanella species (Moule \& Wilkinson, 1987; Russel \& Nichols, 1999). In spite of the variability of the fatty acid composition between Shewanella species, the specific features of this genus are retained.

The 16S rRNA gene sequences of KMM $3823^{\mathrm{T}}$ and related sequences were selected within a database of 65000 already aligned bacterial 16S rRNA gene sequences. Selection of sequences was according to previous phylogenetic analyses of the entire database and blasts against the latest release of EBI (12 January 2003), with the 'no filter' option. The 100 most similar sequences were used to calculate the percentages of $16 \mathrm{~S}$ rRNA gene similarity with other available sequences. Calculation was done by parsing the result of this BLAST analysis and summing over the various highscoring segment pairs (HSP; ungapped BLAST) if necessary. Sequence similarities were calculated with BLAST, as there is no recognized rule to calculate a percentage of similarity and BLAST is widely used for that purpose. Because

Table 1. Characteristic cellular fatty acid composition of Shewanella waksmanii and phylogenetically related species

Taxa: 1, Shewanella waksmanii KMM $3823^{\mathrm{T}}$; 2, Shewanella fidelis $\mathrm{KMM} 3582^{\mathrm{T}}$; 3, Shewanella pealeana ATCC $700345^{\mathrm{T}} ; 4$, Shewanella gelidimarina ACAM $456^{\mathrm{T}} ; 5$, Shewanella violacea JCM $10179^{\mathrm{T}}$; 6. Shewanella benthica ATCC $43992^{\mathrm{T}}$; 7, Shewanella woodyi ATCC $51908^{\mathrm{T}}$; 8, Shewanella hanedai CIP $103207^{\mathrm{T}}$. Data from this study, Nogi et al. (1998), Venkateswaran et al. (1999), Makemson et al. (1997) and Ivanova et al. (2003). A table showing the complete cellular fatty acid compostion of Shewanella waksmanii is available as supplementary data in IJSEM Online.

\begin{tabular}{|c|c|c|c|c|c|c|c|c|}
\hline Fatty acid & 1 & 2 & 3 & 4 & 5 & 6 & 7 & 8 \\
\hline \multicolumn{9}{|c|}{ Saturated straight-chain } \\
\hline $12: 0$ & 2 & $1 \cdot 5$ & $0 \cdot 2$ & & 4 & 5 & $4 \cdot 6$ & $0 \cdot 3$ \\
\hline $14: 0$ & $1 \cdot 7$ & $2 \cdot 0$ & $2 \cdot 6$ & $5 \cdot 2$ & 6 & 17 & $6 \cdot 42$ & $9 \cdot 1$ \\
\hline $15: 0$ & $5 \cdot 3$ & $10 \cdot 6$ & $1 \cdot 2$ & $3 \cdot 8$ & 7 & & $4 \cdot 8$ & $5 \cdot 0$ \\
\hline $16: 0$ & $6 \cdot 2$ & $9 \cdot 9$ & $24 \cdot 9$ & $13 \cdot 9$ & 16 & 15 & $26 \cdot 1$ & $21 \cdot 0$ \\
\hline $18: 0$ & $0 \cdot 3$ & & $4 \cdot 1$ & $0 \cdot 3$ & & & & $0 \cdot 5$ \\
\hline \multicolumn{9}{|c|}{ Monounsaturated } \\
\hline $17: 1$ & & & $1 \cdot 2$ & $4 \cdot 2$ & 2 & & $1 \cdot 6$ & $2 \cdot 4$ \\
\hline $16: 1(n-7)$ & $9 \cdot 8$ & $20 \cdot 0$ & $19 \cdot 4$ & $27 \cdot 9$ & 19 & 37 & $16 \cdot 2$ & $18 \cdot 6$ \\
\hline $18: 1(\mathrm{n}-7)$ & 2 & $4 \cdot 5$ & $6 \cdot 3$ & $6 \cdot 8$ & 5 & 1 & & $1 \cdot 4$ \\
\hline \multicolumn{9}{|l|}{ Branched } \\
\hline $13: 0$ iso & 10 & $7 \cdot 7$ & $2 \cdot 6$ & $8 \cdot 0$ & 8 & 11 & $10 \cdot 5$ & $5 \cdot 8$ \\
\hline $15: 0$ iso & $32 \cdot 5$ & $16 \cdot 6$ & $8 \cdot 4$ & $13 \cdot 2$ & 14 & 5 & $14 \cdot 3$ & $4 \cdot 6$ \\
\hline \multicolumn{9}{|c|}{ Polyunsaturated } \\
\hline $20: 4 \mathrm{n}-3$ & & & $1 \cdot 6$ & $0 \cdot 7$ & & & & $1 \cdot 4$ \\
\hline $20: 5 n-5$ & $6 \cdot 7$ & & $19 \cdot 1$ & $14 \cdot 0$ & 15 & 8 & & $23 \cdot 1$ \\
\hline
\end{tabular}


Table 2. Characteristics that differentiate Shewanella waksmanii from phylogenetically related species

Taxa: 1, Shewanella waksmanii KMM $3823^{\mathrm{T}}$; 2, Shewanella fidelis $\mathrm{KMM} 3582^{\mathrm{T}}$; 3, Shewanella pealeana ATCC $700345^{\mathrm{T}}$; 4 , Shewanella gelidimarina ACAM $456^{\mathrm{T}} ; 5$, Shewanella hanedai CIP $103207^{\mathrm{T}} ; 6$, Shewanella woodyi ATCC $51908^{\mathrm{T}}$; 7 , Shewanella colwelliana ATCC 33888 ; 8, Shewanella benthica ATCC $43992^{\mathrm{T}}$; 9, Shewanella violacea JCM $10179^{\mathrm{T}}$. All strains are straight, rod-shaped organisms, oxidase- and catalase-positive, produce $\mathrm{H}_{2} \mathrm{~S}$, do not utilize sucrose, D-fructose, fumarate or glycerol. V, Variable reaction depending on the strain; ND, data not available. Data from this study, Weiner et al. (1998), Bowman et al. (1997), Nogi et al. (1998), Venkateswaran et al. (1999) and Ivanova et al. (2003).

\begin{tabular}{|c|c|c|c|c|c|c|c|c|c|}
\hline Characteristic & 1 & 2 & 3 & 4 & 5 & 6 & 7 & 8 & 9 \\
\hline Optimal growth temp. $\left({ }^{\circ} \mathrm{C}\right)$ & $20-22$ & $20-25$ & $25-28$ & $15-17$ & $\leqslant 25$ & 25 & 25 & $4-15$ & 8 \\
\hline Growth at $30^{\circ} \mathrm{C}$ & + & + & + & - & - & + & + & - & - \\
\hline Growth at $0 \% \mathrm{NaCl}$ & - & + & - & - & - & - & - & ND & - \\
\hline Growth at $8 \% \mathrm{NaCl}$ & - & + & - & - & - & - & - & + & - \\
\hline Haemolysis & + & + & - & - & $\mathrm{ND}$ & $\mathrm{ND}$ & $\mathrm{ND}$ & $\mathrm{ND}$ & $\mathrm{ND}$ \\
\hline \multicolumn{10}{|l|}{ Production of: } \\
\hline Lipase & + & $\mathrm{V}$ & + & + & + & - & ND & - & ND \\
\hline Amylase & - & - & - & + & - & $\mathrm{V}$ & + & - & - \\
\hline Gelatinase & + & + & - & + & + & + & + & + & + \\
\hline D-Galactose & - & - & + & - & + & + & - & + & + \\
\hline DL-Lactate & - & - & + & + & ND & ND & - & $\mathrm{ND}$ & $\mathrm{ND}$ \\
\hline Succinate & - & - & + & - & $\mathrm{ND}$ & ND & - & + & ND \\
\hline Citrate & - & - & + & - & - & - & - & - & $\mathrm{ND}$ \\
\hline
\end{tabular}

percentage similarity calculation relies on the method of alignment, it does not take into account the fact that transitions are more likely than transversions (contrary to distances calculated in phylogeny) and finally does not take into account that two random sequences of similar length have $25 \%$ similarity. A first phylogenetic tree containing 100 sequences was thus built using neighbourjoining. This tree was reduced by keeping only sequences of type strains (one sequence per type strain). Phylogenetic trees were then constructed using three different methods (bioNJ, maximum-likelihood and maximum-parsimony). For the NJ analysis, distance matrices were calculated using the Kimura two-parameter correction (in contrast to similarity calculations, theoretical calculations have shown that distance corrections need to be used in phylogeny). For the final tree, 32 sequences of strains closely related to KMM $3823^{\mathrm{T}}$ were retained. Because of close relationships, no evident homoplasy was detected and almost the entire sequences corresponding to positions 253-1459 of KMM 3823 type strain was used for that analysis (the short sequence of Shewanella baltica required to reduce the domain analysed). The phylogenetic trees were drawn using NJPLOT (Perrière \& Gouy 1996). The topology shown is that of the bootstrap tree as it has been demonstrated that this topology is often better than that of a simple NJ or MP analysis (Berry \& Gascuel 1996). There is no distance bar in
Fig. 1 since it would be meaningless because (i) distances are corrected (see above) and (ii) this is a bootstrap tree. Finally the tree shown is rooted as it is a subset of the tree obtained by extracting the first robust clade up from the Shewanella waksmanii leaf. Shewanella waksmanii clustered with Shewanella colwelliana only in the NJ analysis. In parsimony and maximum-likelihood analyses, it had no sister taxon.

We can note that strain KMM $3823^{\mathrm{T}}$ formed a distinct branch inside the robust cluster that comprised species Shewanella fidelis, Shewanella hanedai, Shewanella woodyi, Shewanella gelidimarina, Shewanella colwelliana, Shewanella pealeana, Shewanella benthica, Shewanella violacea, Shewanella schlegeliana, Shewanella marinitestina and Shewanella sairae. Thus, the closest phylogenetically related species listed above have only $96 \cdot 6 \%$ or less $16 \mathrm{~S}$ rRNA gene sequence similarities to KMM $3823^{\mathrm{T}}$ and low levels of genetic relatedness (16-9\%), it is concluded that strains KMM $3823^{\mathrm{T}}$ and 3836 belong to a distinct species. Bacteria of the new species can be phenotypically distinguished from Shewanella fidelis and other species by the following combination of phenotypic traits, e.g. the presence of greenish-brown pigment, haemolytic and elastase activity, obligate requirement in $\mathrm{Na}$ ions, $\mathrm{NaCl}$ tolerance and different proportions of $15: 0$ iso and $16: 1(n-7)$ fatty 
acids (Table 1-2). In conclusion, genetic and phylogenetic analyses of 16S rRNA gene sequences are consistent with phenotypic characteristics to suggest that the two strains represent a new species of Shewanella.

\section{Description of Shewanella waksmanii sp. nov.}

Shewanella waksmanii (waks' ma.ni.i. N.L. gen. n. waksmanii in honour of the 1952 Nobel Laureate in Physiology and Medicine, Selman A. Waksman, who isolated and characterized a number of microbial antibiotics and who made an important contribution to development of marine bacteriology).

Cells are rod-shaped, $1-2 \mu \mathrm{m}$ in length and $0 \cdot 6-0 \cdot 8 \mu \mathrm{m}$ in diameter, polarly flagellated and Gram-negative, facultatively anaerobic heterotrophs. Anaerobic growth occurs by fermentation of D-glucose by anaerobic respiration of nitrate. Endospores are not formed. Colonies on Marine 2216 agar are circular, smooth and convex with an entire edge, greenish-brown. Organic growth factors are not required. Growth occurred at $1-6 \%$ of $\mathrm{NaCl}$. Grows at $4-30{ }^{\circ} \mathrm{C}$ (optimum $20-25^{\circ} \mathrm{C}$ ); does not grow at $35^{\circ} \mathrm{C}$. $\mathrm{pH}$ range for growth is $6 \cdot 0-10 \cdot 0$ (optimum $\mathrm{pH} 7 \cdot 5$ ). Oxidase and catalase-positive. Haemolytic. Exhibits alginase, elastase and DNase activities. Starch, chitin, agar, alginate and laminaran are not hydrolysed. Susceptible to ampicillin, carbenicillin, gentamicin and kanamycin. D-Glucose utilized as a sole source of carbon. Does not utilize D-galactose, D-fructose, $\mathrm{N}$-acetylglucosamine, succinate, acetate, cellobiose, D-mannose, sucrose, lactose, fumarate, glycerol, $\gamma$-aminobutyrate, L-tyrosine. The list of carbon sources oxidized according to Biolog is given in the text. The major cellular fatty acids are i-13:0, i-15:0, 16:0, $16: 1(n-7)$ and $20: 5(n-3)$.

Based on 16S rRNA gene sequences, belongs to the 'Gammaproteobacteria'. Isolated from the sipuncula Phascolosoma japonicum in Troitsa Bay in the Gulf of Peter the Great (Sea of Japan). The DNA G $+\mathrm{C}$ content is $43.0 \mathrm{~mol} \%$. Type strain is $\mathrm{KMM} 3823^{\mathrm{T}}\left(=\mathrm{CIP} 107701^{\mathrm{T}}\right.$ $=$ ATCC BAA- $643^{\mathrm{T}}$ ).

\section{Acknowledgements}

This study was partially supported by funds from the Russian Foundation for Basic Research (RFBR) \#02-04-49517, Grant \# 03-19 from Ministry for Industry, Science and Technology of Russian Federation, and partially supported by the Science Support Foundation RAS grant for talented researchers.

\section{References}

Barry, A. I. (1980). Procedures and theoretical considerations for testing antimicrobial agents in agar media. In Antibiotics in Laboratory Medicine, pp. 10-16. Edited by V. Logan. Baltimore: Williams \& Wilkins.

Baumann, L., Baumann, P., Mandel, M. \& Allen, R. D. (1972). Taxonomy of aerobic marine eubacteria. J Bacteriol 110, 402-429.

Berry, V. \& Gascuel, O. (1996). Interpretation of bootstrap trees: threshold of clade selection and induced gain. Mol Biol Evol 13, 999-1011.
Bowman, J. P., McCammon, S. A., Nichols, D. S., Skerratt, J. H., Rea, S. M., Nichols, P. D. \& McMeekin, T. A. (1997). Shewanella gelidimarina sp. nov. and Shewanella frigidimarina sp. nov., novel Antarctic species with the ability to produce eicosapentaenoic acid $(20: 5 \omega 3)$ and grow anaerobically by dissimilatory Fe(III) reduction. Int J Syst Bacteriol 47, 1040-1047.

Ezaki, T., Hashimoto, Y., Takeuchi, N., Yamamoto, H., Liu, S.-L., Miura, H., Matsui, K. \& Yabuuchi, E. (1988). Simple genetic method to identify viridans group streptococci by colorimetric dot hybridization and fluorometric hybridization in microdilution wells. J Clin Microbiol 26, 1708-1713.

Gascuel, O. (1997). BIONJ: an improved version of the NJ algorithm based on a simple method of sequence data. Mol Biol Evol 14, 685-695.

Gauthier, G., Gauthier, M. \& Christen, R. (1995). Phylogenetic analysis of the genera Alteromonas, Shewanella, and Moritella using genes coding for small-subunit rRNA sequences and division of the genus Alteromonas into two genera, Alteromonas (emended) and Pseudoalteromonas gen. nov., and proposal of twelve new species combinations. Int J Syst Bacteriol 45, 755-761.

Ivanova, E. P., Kiprianova, E. A., Mikhailov, V. V., Levanova, F. G., Garagulya, A. D., Gorshkova, N. M., Yumoto, N. \& Yoshikawa, S. (1996). Characterization and identification of marine Alteromonas nigrifaciens strains and emendation of the description. Int $J$ Syst Bacteriol 46, 223-228.

Ivanova, E. P., Sawabe, T., Gorshkova, N. M., Svetashev, V. I., Mikhailov, V. V., Nicolau, D. V. \& Christen, R. (2001). Shewanella japonica sp. nov. Int J Syst Evol Microbiol 51, 1027-1033.

Ivanova, E. P., Sawabe, T., Hayashi, K., Gorshkova, N. M., Zhukova, N. V., Nedashkovskaya, O. I., Mikhailov, V. V., Nicolau, D. V. \& Christen, R. (2003). Shewanella fidelis sp. nov., isolated from sediments and sea water. Int J Syst Evol Microbiol 53, 577-582.

MacDonell, M. T. \& Colwell, R. R. (1985). Phylogeny of the Vibrionaceae, and recommendation for two new genera, Listonella and Shewanella. Syst Appl Microbiol 6, 171-182.

Marmur, J. (1961). A procedure for the isolation of deoxyribonucleic acid from microorganisms. J Mol Biol 3, 208-218.

Makemson, J. C., Fulayfil, N. R., Landry, W., Van Ert, L. M., Wimpee, C. F., Widder, E. A. \& Case, J. F. (1997). Shewanella woodyi sp. nov., an exclusively respiratory luminous bacterium isolated from the Alboran Sea. Int J Syst Bacteriol 47, 1034-1039.

Moule, A. L. \& Wilkinson, S. G. (1987). Polar lipids, fatty acids and isoprenoid quinones of Alteromonas putrefaciens (Shewanella putrefaciens). Syst Appl Microbiol 9, 192-198.

Myers, C. R. \& Nealson, K. H. (1988). Bacterial manganese reduction and growth with manganese oxide as the sole electron acceptor. Science 240, 1319-1321.

Nogi, Y., Kato, C. \& Horikoshi, K. (1998). Taxonomic studies of deep-sea barophilic Shewanella strains and description of Shewanella violacea sp. nov. Arch Microbiol 170, 331-338.

Perrière, G. \& Gouy, M. (1996). WWW-Query: an on-line retrieval system for biological sequence banks. Biochimie 78, 364-369.

Petrovskis, E. A., Vogel, T. M. \& Adriaens, P. (1994). Effects of electron acceptors and donors on transformation of tetrachloromethane by Shewanella putrefaciens MR-1. FEMS Microbiol Lett 121, 357-364.

Russell, N. J. \& Nichols, D. S. (1999). Polyunsaturated fatty acids in marine bacteria - a dogma rewritten. Microbiology 145, 767-779.

Sawabe, T., Makino, H., Tatsumi, M., Nakano, K., Tajima, K., Iqbal, M. M., Yumoto, I., Ezura, Y. \& Christen, R. (1998). Pseudoalteromonas bacteriolytica sp. nov., a marine bacterium that is causative agent of red spot disease of Laminaria japonica. Int J Syst Bacteriol 48, 769-774. 
Semple, K. M. \& Westlake, D. W. S. (1987). Characterization of iron reducing Alteromonas putrefaciens strains from oil field fluids. Can J Microbiol 35, 925-931.

Smibert, R. M. \& Krieg, N. R. (1994). Phenotypic characterization. In Methods for General and Molecular Bacteriology, pp. 607-654. Edited by F. Gerhardt \& 11 other editors. Washington, DC: American Society for Microbiology.

Stackebrandt, E. \& Goebel, B. M. (1994). Taxonomic note: a place for DNA-DNA reassociation and $16 \mathrm{~S}$ rRNA sequence analysis in the present species definition. Int $J$ Syst Bacteriol 44, 846-849.

Svetashev, V. I., Vysotskii, M. V., Ivanova, E. P. \& Mikhailov, V. V. (1995). Cellular fatty acid of Alteromonas species. Syst Appl Microbiol 18, 37-43.
Tamaoka, J. \& Komagata, K. (1984). Determination of DNA base composition by reverse phase high-performance liquid chromatography. FEMS Microbiol Lett 25, 125-128.

Venkateswaran, K., Moser, D. P., Dollhopf, M. E. \& 10 other authors (1999). Polyphasic taxonomy of the genus Shewanella and description of Shewanella oneidensis sp. nov. Int J Syst Bacteriol 49, 705-724.

Wayne, L. G., Brenner, D. J., Colwell, R. R. \& 9 other authors (1987). International Committee on Systematic Bacteriology. Report of the ad hoc committee on reconciliation of approaches to bacterial systematics. Int J Syst Bacteriol 37, 463-464.

Weiner, R. M., Coyne, V. E., Brayton, P., West, P. \& Raiken, S. F. (1988). Alteromonas colwelliana sp. nov., an isolate from oyster habitats. Int J Syst Bacteriol 38, 240-244. 